\title{
The Perfect Ruler in the Art and Literature of Medieval Bulgaria*
}

There is no surviving literary text of medieval Bulgaria that explicitly expresses the concept of the perfect ruler. Yet there are other sources, both verbal and visual, providing us with information on that issue. In this paper I try to present some of them, related to the image of the Bulgarian king Ivan Alexander (1331-1371). I focus on him mostly because the $14^{\text {th }}$ century - an extremely important period in medieval Bulgarian culture - is still subject to unfinished research, scholarly discussion and re-assessment. On the other hand, Ivan Alexander is the only Bulgarian ruler whose images survived in great number. Chronologically, they cover almost the entire period of his relatively long and successful reign.

My long research on the king's images in Bulgarian medieval art has naturally led me to the written depictions preserved in Old Bulgarian manuscripts, among which the most detailed is the one contained in the famous encomium of the king, part of the Sofia Psalter (1337). This is a short text, included in the manuscript of a Psalter ordered by Ivan Alexander and written in the monastery of Kouklen, which is now kept in the library of the Bulgarian Academy of Sciences (and hence is known as the Sofia Psalter) ${ }^{1}$. The encomium itself is interpolated after the psalms and the fifth song by Isaiah.

In his book Портрет у српској средновековној книжевности (Kruševac 1971), George Trifunović writes about this portrait as follows:

\footnotetext{
* The main part of this paper was written during my stay in Munich and Berlin within an Alexander von Humboldt' Grant. I owe special thanks to Prof. Franz Tinnefeld of the Institut für Byzantinistik und Neogräzistik der Universität München and Prof. Diether Reinsch of ByzantinischNeugriechisches Seminar der Freien Universität Berlin, with whom I had the chance to discuss some of the issues addressed here. The following versions of this paper have already been published: Е. БАКАлова, Портретьт на Цар Иван Александър в Софийския песнивеи: "реализбм" или компилация от топоси?, [in:] Словенско средновековно наслеђе. Зборник посвећен nрофесору Борђу Трифуновићу, Београд 2002, р. 45-58; ЕADEM, The Image of the Ideal Ruler in Medieval Bulgarian Literature and Art, [in:] Les cultes des saints guerriers et idéologie du pouvoir en Europe Centrale et orientale. Actes du colloque international 17 janvier 2004, New Europe College, ed. I. Biliarski, R. PĂUn, Bucarest 2007, p. 34-81.

1 For the newest research on this manuscript, together with all the preceding references, see Е. Мусакова. Кодикологически особености на Песнивеца на иар Иван Александър, Pbg 26.2, 2002, p. 3-33.
} 
У краткој похвали бугарском цару Ивану Александру, записаној на Псалтиру из 1337 године, писац саопштава и једну необичну појединост о усправном ходану са савијеним коленима. Преписвач псалтира и писац похвале као да међу општа места уноси и стварни особени податак: Господ нам

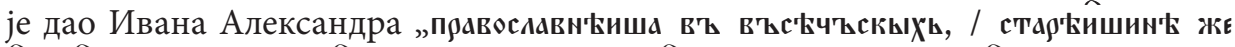

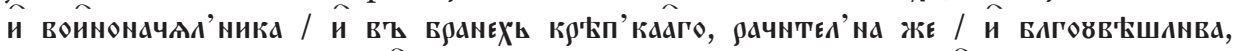

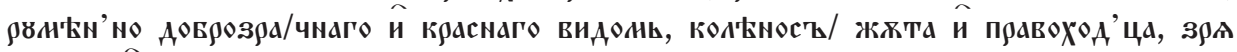

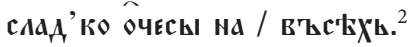

The Bulgarian scholar K. Kuev is very deleted: this is a work by our own author who has the right to claim originality. Moreover, in his article, titled The image of Ivan Alexander in medieval Bulgarian poetry (sic!), Kuev calls this text an 'solemn hymn'3. A bit later in vol. II of the edition Old Bulgarian literature: Oratory prose, L. Graševa attributes the encomium of king Ivan Alexander to the genre 'oratory prose' ${ }^{4}$. These contradictory opinions of distinguished literary scholars about the specific genre and the originality of the text ${ }^{5}$ incited me to do my own research, the results of which I present in this paper.

First, I discuss the question of genre. It suffices to consider the treatise $\Pi \varepsilon p i$ $\dot{\varepsilon} \pi \delta \varepsilon \iota \kappa \tau \iota \kappa \omega \dot{\omega}$ by the famous sophist, orator and teacher of rhetoric, Menander of Laodicea (late $3^{\text {rd }}$ - early $4^{\text {th }} \mathrm{c}$.), in order to assure ourselves that our 'encomium' is

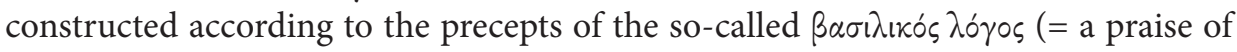
the emperor).

I focus on this author, because his writings are used in the entire late Byzantine literature of praise and mostly in the so-called $\beta \alpha \sigma \imath \lambda \iota$ кós $\lambda$ ó $\gamma \circ$ s. According to Menander, any encomium of this kind: It will thus embrace a generally agreed amplification

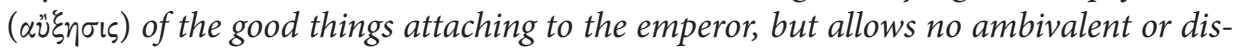
puted features, because of the extreme splendor of the person concerned ${ }^{6}$. After the proem, depending on the occasion, the author should deal briefly or in more detail with

2 Ђ.Трифуновић, Портрет у српској средњовековној књижевности, Крушевац 1971, p. 19.

3 К. Куев, Образбт на Иван Александър в среднобългарската поезия, [in:] Бблгарско средновековие. Българо-съветски сборник в чест на 70-годишнината на проф. И. Дуйчев, София 1980, p. 256.

4 Стара българска титература, t. II, Ораторска проза, sel. et ed. Л. Грашева, София 1982, p. $146-147$.

5 The original text is published by: Б. Цонев, Славянски ръкописи в Българската академия, СбБАН, 6, 1916, p. 10-11. See also Х. Кодов, Опис на славянските ргкописи в Библиотеката на Българската академия на науките, София 1969, p. 11-16. The Bulgarian translation is made by И. Дуйчев. Из старата българска книжнина, t. II, София 1944, p. 69-72; also in: П. ДинеКОв, К. Куев, Д. ПЕТКАНОвА, Христоматия по старобългарска литература, София 1961, p. 274-275; П. Динеков. Старобългарски страници. Антология, София 1966, p. 54-55.

6 From here on we use the bilingual edition: Menander Rhetor, ed. et trans. D.A. Russell, N.G. WiLson, Oxford 1981, p. 76-77. 
the emperor's native land ( $\pi \alpha \tau$ pi $\varsigma$ ) and his family ( $\gamma \varepsilon \dot{\varepsilon} \circ \varsigma$ ), as well as with the extraordinary circumstances of his birth ( $\gamma \varepsilon \dot{\varepsilon} \nu \eta \sigma i \varsigma)$. However, since Menander's precepts vary, he notes: If neither his city nor his nation is conspicuously famous, you should omit this topic, and consider whether his family has prestige or not. If it has, work this up... What follows are the nature ( $\phi \dot{v} \sigma \varsigma)$, upbringing ( $\left.\alpha \nu \alpha \tau \rho \circ \phi \eta^{\prime}\right)$ and attitudes of character

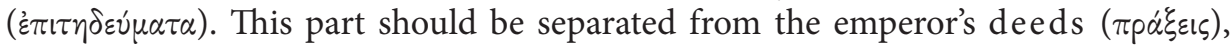
which are the main subject-matter of the author. You should divide - Menander continues - such 'actions' into times of peace and times of war, and put war first, if the subject of your praise has distinction in this ${ }^{8}$. And further on, he adds: Courage reveals an emperor more than do other virtues. If however, he has never fought a war (a rare circumstance), you have no choice but to proceed to peaceful topics 9 .

What we said so far, makes it clear that the author of the encomium of Ivan Alexander did not by himself finds it necessary to first depict the king's external image and only then to focus on his deeds ${ }^{10}$, as Kuev thinks, but he was obviously familiar with the principles of constructing a praise of this kind, as short as it may be. That the author's admiration is first of all due to the king's military success ${ }^{11}$ (K. Kuev) turns out to be an act of strictly following the compositional rules of that genre in Byzantine literature $^{12}$. Needless to say, our author has the particular advantage that Ivan Alexander really was victorious in war and he could "develop this in detail". It is precisely here that what is specific about the king himself intrudes into the text without changing the system of pictorial means, as L. Graševa justly points out regarding oratory prose, in her preface to the above-mentioned book ${ }^{13}$.

This interpretation is also confirmed by other elements of the text under discussion. For instance, Menander emphasizes that the emperor's deeds should be spoken of as the four cardinal virtues: courage ( $\dot{\alpha} \nu \delta \rho \varepsilon i \alpha)$, justice ( $\delta$ เ $\alpha\llcorner\circ \sigma \dot{v} \nu \eta)$, temperance

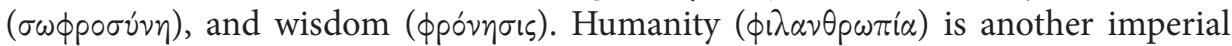
virtue worth discussing ${ }^{14}$. For this reason our text refers to Ivan Alexander not only as mighty in battle, but also as a "pious judge of orphans and widows" and comforter of his subjects (who ... once having the king shall return to his home in sorrow?).

Menander also prescribes a comparison of the king with Alexander the Great. In fact, at any moment (part) of the speech, the orator should use the method of com-

\footnotetext{
7 Ibidem, p. 80-81.

8 Ibidem, p. 84-85.

9 Ibidem, p. 84-85.

${ }^{10}$ К. Куев, op. cit., p. 256.

${ }^{11}$ Ibidem, p. 257.

${ }^{12}$ Menander points at this as follows: You should also describe the emperor's own battles, and incest him with all impressiveness and knowledge, as Homer does for Achilles, Hector and Ajax, see MENANDER RHETOR, op. cit., p. 86-87.

13 Л. ГрАшевА, Поглед към старобблгарската ораторска проза, [in:] Стара българска литература..., p. 19.

${ }^{14}$ Menander Rhetor, op. cit., p. 84-85.
} 


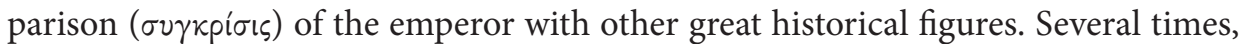
Alexander the Great is suggested as a key figure of comparison: we compare a reign as a whole and in sum with another reign, e.g., the reign of Alexander with the present one $^{15}$ (at one point, the king is named our second Alexander ${ }^{16}$ ).

Menander's rules of composing an epilogue to $\beta \alpha \sigma \imath \lambda$ เ ós $\lambda$ ó $\gamma \circ \varsigma$ are also generally applied in one of the concluding passages of the encomium. The epilogue - Menander says - should be elaborated by having regard to the scope of the subject, representing the inhabitants greeting the governor: 'We have come to meet you, all of us, in whole families, children, old men, adults, priestly clans, associations of public men, the common people, greeting you with joy, all welcoming thou with cries of praise, calling you our savior and fortress, our bright star'... ${ }^{17}$ The praise should conclude with a prayer for the emperor's long reign, and then move on to his heirs ${ }^{18}$. So does our text: Look, all you young and old, and raise your flags in combats for the glorious King of Bulgaria. Come forth, now you patriarchs and bishops, monks and ascetics, judges, slaves and freemen, dignitaries and all the king's men; and rejoice you with inexpressible joy... And further: Oh, Holy Trinity, save the Bulgarian King, protect and strengthen him, give him victory over his enemies and ... endow him with longevity.

Here it is worth recalling that rhetorical techniques of praising the emperor were implemented before the Christianization and, consequently, Menander's rules were used by both pagan and Christian orators ${ }^{19}$. However, his encomiastic model was enriched and modified according to the needs of Christian propaganda. In the later Byzantine tradition, we find a new Christian layer of descriptive conventions. This "Christian discourse", as A. Cameron calls it ${ }^{20}$, emphasizes the emperor's piety, humanity and generosity. The most important new element is the link between the Christian ruler and Christ who announced him as his earthly minister. This ideal adds new comparisons with biblical and Christian rulers, mainly with David, Solomon and Constantine.

The new elements can be found as early as Constantine's reign, for example in such an emblematic piece of Byzantine prose, as Constantine's encomium by Eusebius of Caesarea delivered on the occasion of the thirtieth anniversary of the reign of

${ }^{15}$ Ibidem, p. 92-93.

${ }^{16}$ Ibidem, p. 112-113, 186-187.

${ }^{17}$ Ibidem, p. 100-101.

${ }^{18}$ Ibidem, p. 94-95.

${ }^{19}$ H. Hunger, Die hochsprachliche profane Literatur der Byzantiner, München 1978, vol. I, p. 80, 88sq, 90-93, 105, 121sq, 132sq, 134; cf. G. Bowersock, Julian the Apostate, London 1978, p. 37; D. Russell, Epideictic Practice and Theory, [in:] Menander Rhetor, XI-XLVI. Cf. IDEm, The panegyrists and their Teachers, [in:] The Propaganda of Power. The Role of Panegyric in Late Antiquity, ed. M. Wнітву, Leiden-Boston-Köln 1998, p. 17-53 (with rich bibliography).

${ }^{20}$ I mean by it all the rhetorical strategies and manners of expression that take to be particularly characteristic of Christian writing, see A. CAMERon, Christianity and Rhetoric of Empire: The Development of Christian Discourse, Berkeley 1991, p. 5. 
Constantinople's founder ${ }^{21}$. From then on, these elements vary in the great number of encomia of the subsequent Byzantine emperors. Moreover, it is precisely Constantine who became an idealized archetype of the Christian ruler, a symbol of the emperor's legitimacy and identity and a model for comparison ${ }^{22}$. From Tiberius to Michael VIII Palaeologus, who calls himself "a new Constantine", most Byzantine emperors either took the name "Constantine" or called themselves "a new Constantine". Recently, the well-known Byzantine scholar, Paul Magdalino, rightly titled a collection of papers "New Constantines. The Rhythm of imperial renewal in Byzantium $4^{\text {th }}-13^{\text {th }} c$."23

Thus Constantine not only became the standard image of Byzantine ideology, also shown in the specific genre of Fürstenspiegel ${ }^{24}$, but was also set as a model for the rulers of all other orthodox (or just Christian) kingdoms. It suffices to recall Patriarch Photius' letter to the Bulgarian king Boris-Michael ${ }^{25}$.

This, let us say Christian, layer is undoubtedly present in our text; it simply imposes itself on Menander's scheme. In the beginning the praise goes first to Christ who gave us a great leader and king of kings, the great Ivan Alexander, the most orthodox of all ... In the second part, after having compared the king with Alexander the Great, comes the comparison with Constantine: It seems to me that our king appeared as a new Constantine among all kings in faith and piety, heart and character, carrying with himself the victorious Cross as his scepter. By showing this herald he repelled and dispelled all opposing forces of pride. It is obvious that the main theme "worked out" in the encomium is the military success and the fortification of the kingdom, as a result of the king's deeds (a theme considered essential by Menander, as well). The comparison with Alexander the Great allows him to emphasize his military force,

\footnotetext{
${ }^{21}$ Eusebius, Werke, vol. I, Oratio de laudibus Constantini (Tricennalia), ed. I.A. Heikel, Leipzig 1902. Cf. H.A. Drake, In Praise of Constantine. A Historical Study and New Translation of Eusebius' Tricennial Oration, Berkeley-Los Angeles-London 1976, p. 87 [III(5)]; p. 94 sq [VI(18)].

${ }_{22}$ See especially O. Treitinger, Die oströmische Kaiser und Reichsidee nach ihrer Gestaltung in höfischen Zeremoniel vom oströmischen Staats- und Reichsgedanken, Darmstadt 1956, p. 129-134; A. LINDER, The Myth of Constantine the Great in West: Sources and Hagiographic Commemorations, SMed 16, 1975, p. 43-95; H. Hunger, op. cit., p. 72, 249, 280, 286; A. KAZHDAN, "Constantine imaginaire". Byzantine Legends of the Ninth Century about Constantine the Great, B 57, 1987, p. 196-250; D. Nicol, The Immortal Emperor, Cambridge 1992; Н. РАдошевит, Константин Велики у "Царским говорима", ЗРВИ 33, 1994, p. 7-19. I owe gratitude to the recently deceased N. Radošević for her comments and suggestions.

${ }^{23}$ New Constantines. The Rhythm of imperial renewal in Byzantium. $4^{\text {th }}-13^{\text {th }}$ c., ed. P. Magdalino, Aldershot 1955.

${ }^{24}$ H. Hunger, op. cit., 157-165; I. ŠEvČEnko, Agapetus East and West: the Fate of Byzantine Mirror of Princes, RESEE 16, 1978, p. 3-44; W. BLum, Byzantinische Fürstenspiegel. Agapetos, Theophylakt von Ochrid, Thomas Magister, Stuttgart 1981, p. 102, 140; G. Prinzing, Beobachtungen zu 'integrierten' Fürstenspiegeln der Byzantiner, JÖB 38, 1988, p. 1-33.

${ }^{25}$ You have done a deed which compares with the achievements of the great Constantine (see English translation in: The Patriarch and the Prince. The letter of Patriarch Photios of Constantinople to Khan Boris of Bulgaria, ed. D. Stratiudaki-White, J.R. Berrigen, Brookline Mass. 1982, p. 56).
} 
while the comparison with Constantine, allows him to give the main reason for his victories. Needless to say, the comparison of Ivan Alexander with Constantine is also attested in other texts and in the fine arts, for example in the ossuary of the Backovo monastery, where the king's image is juxtaposed to the images of Sts. Constantine and Helen ${ }^{26}$. In our text there are also other epithets and elements of praise, typical of the image of Byzantine emperors, such as the most orthodox, philanthropous, merciful (benevolent), etc. ${ }^{27}$

Related to the same Christian layer (but only to some extent) is the conclusion of the text, particularly the so-called 'chaeretisms' (Rejoice! Rejoice!) They are obviously influenced by the Akathistos hymn for the Virgin and by the praises of some Saints, known in Old Bulgarian literature, as noted by $\mathrm{Kuev}^{28}$, as well as by an appeal to the Holy Trinity. As was said above, Menander prescribes that the epilogue should present the population praising the king. Besides, I note that the whole mise en scène of the exultant people, raising flags and singing victorious songs for the king, in fact representing all social classes, necessarily remind us of the adventus ceremony from Roman antiquity, preserved in the Middle Ages as a way of celebrating the triumphant return of the rulers (bishops and other holy persons, as well as holy relics). During this ceremony, the entire population - men, women, young and old, are greeting those who return with various gestures, acclaims and songs $\mathrm{s}^{29}$.

Here I add a few words on the description of the king's appearance. The standard descriptions of an emperor's appearance in Byzantine encomiastic literature are "ruddy, affable and handsome", inherited from the rhetorical model in antiquity ${ }^{30}$.

As Maciej Kokoszko notes, the adjective "ruddy", describing the color of the emperor's face refers to his healthy blood, according to the ancient authors, as well as Origenes ${ }^{31}$. For instance, Anna Comnena says that the facial skin of Alexius I Comnenus was white to ruddy $y^{32}$. Affable means eyes expressing goodness and in dif-

\footnotetext{
${ }^{26}$ Е. БАКАЛОвА, Бачковската костница, София 1977, p. 157-175; cf. The Ossuary of the Bachkovo monastery, ed. EADEM, Plovdiv 2003, p. 118-119.

${ }^{27}$ И. Божилов, Византийският василевс, [in:] И. Божилов, И. Билярски, Х. Димитров, И. ИлиЕв, Византийските василевси, София 1997, р. 26.

${ }^{28}$ К. Куев, op. cit., p. 258.

${ }^{29}$ E. Kantorowicz, Laudes Regiae. Study in Liturgical Acclamations and Medieval Ruler Worship, Berkeley-Los Angeles 1946; S. MacCormack, Change and Continuity in Late Antiquity: The Ceremony of Adventus, Hi 21, 1972, p. 721-752. See also S. MaCCormaCK, Art and Ceremony in Late Antiquity, Berkeley 1981; M. MсCовміск, Eternal Victory. Triumphal Rulership in Late Antiquity, Byzantium and the Early Medieval West, Cambridge 1986.

${ }^{30}$ The ancient models of describing the ruler's appearance used by Byzantine authors are treated in detail by: M. Кокозzко, Descriptions of the personal appearance in John Malalas' chronicle, Łódź 1998 [= BL, 2] (with older literature).

${ }^{31}$ IDEM, Orygenes fizjonomista? Kilka uwag na temat Przeciw Celsusowi I 33, VP 21, 2001, p. 180-181.

${ }^{32}$ IDEM, Kanon portretowania $w$ historiografii bizantyńskiej na przykładzie portretu Boemunda w Aleksjadzie Anny Komneny, AUL.FH 67, 2000, p. 70-71.
} 
ferent versions is part of the description of Roman emperors an Byzantine basileis in John Malalas' Chronicle. (For example, Augustus is said to have good eyes) ${ }^{33}$. In George Skylitzes we find the expression full of goodness ascribed to emperor Valentinianus eyes and also good and grey-blue for Tiberius's eyes. ${ }^{34}$ Handsome is certainly related to the physique and proportions of the king's body, as the villains in the texts are described as misshapen and ill-proportioned ${ }^{35}$. (For instance, Anna Comnena says that the body of Boemund of Tarento was shaped according to Policletus' canon $)^{36}$.

Such rules of presenting the emperor's appearance are typical of other Byzantine authors as well. As Michael Psellus says, the encomium should present that which adorns the hero's soul, which adds beauty to his physique given to him by origin and illumination from above ${ }^{37}$. These requirements regarding the description of the emperor's appearance are also valid for other genres. For example, in his Chronography, Psellus talks of Basil II as merciless, stubborn, energetic, suspicious of all and ruthless ${ }^{38}$, but when speaking about his appearance, he keeps to the encomiastic standard and follows the ancient traditions ${ }^{39}$, despite his earlier assertions. Moreover this inconsistency is pointed out by the author himself who begins his description of the emperor's appearance as follows:

So much for his character. As for his personal appearance it betrayed the natural nobility of the man, for his eyes were light-blue and fiery, the eye-brows not overhanging nor sullen, not yet extended in one straight line, like a women's, but well-arched and indicative of his pride. The eyes were neither deep-set (a sign of knavishness and cunning), but they shone with brilliance that was manly ${ }^{40}$.

Where are the emperor's vivid, individual traits?

Further on in our text we see the most discussed attributes of king Ivan Alexander: with bent knees and a straight walk. The difficulty results from the fact that they lie between the description of the king's appearance and his moral virtues. For the two subsequent determinations looking sweetly with eyes on everyone and ineffable pious judge for orphans and widows certainly refer to the important attributes benevolence, humanity and justice examined above. Here I shall only

${ }^{33}$ IDEM, Descriptions of the personal appearance..., p. 89.

${ }^{34}$ IDEM, Imperial Portraits in George Kedrenos' Chronicle, [in:] Mélanges d'histoire byzantine offerts à Oktawiusz Jurewicz à l’occasion de son soixante-dixième anniversaire, Łódź 1998, p. 155.

${ }_{35}^{35}$ Ibidem, p. 109, passim.

${ }^{36}$ IDEM, Kanon portretowania..., p. 65.

37 Я. ЛюБАРский, Михаил Пселл. Личность и творчество, Москва 1978, p. 231. Cf. P. GAUTIER, "Basilikoi logoi" de Psellos, SG 33, 1980, p. 717-771, passim.

${ }^{38}$ The Chronographia of Michael Psellos, trans. E.R.A. Sewter, London 1953, p. 19, 27.

${ }^{39}$ M. Kокоszко, Platonic foundations of the portrait of Emperor Basil II in the Chronographia by Michael Psellos, CPhil 2, 1995, p. 162-163.

${ }^{40}$ The Chronographia of Michael Psellos..., p. 27. 
note in passing that in my view they also refer to the king's moral virtues. The bent knees which unambiguously remind us of the so-called proskynesis - the act of prostrating before Christ, emphasize the king's piety. I assume that here we find

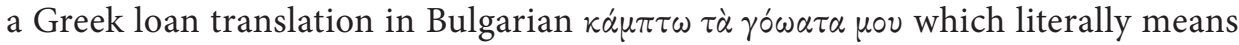
I bend my knees and is used for I prostrate before God. It suffices to recall the corre-

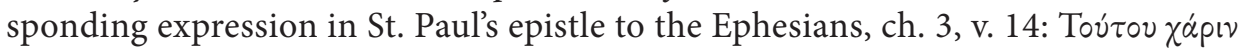

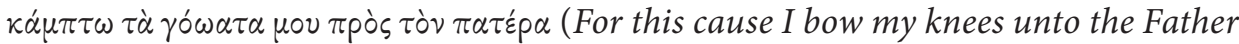
of our Lord Jesus Christ).

In the Bulgarian translation it runs: Затова прекланям колене пред Отеца на Господа нашего Иисуса Христа... This meaning is confirmed by the commentaries on that passage in St. Paul. For instance, we read in Origenes:

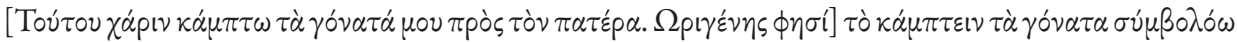

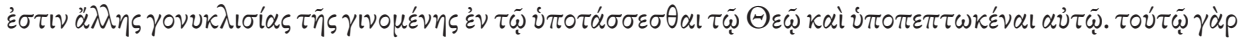

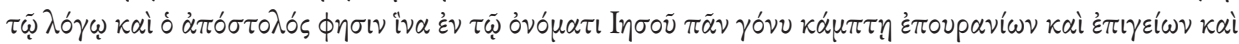

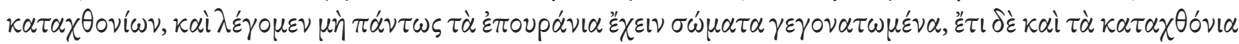

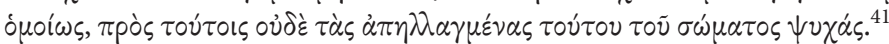

"[Origenes says]: Bending your knees symbolizes another kind of genuflecting, in submission to God and admission of His power. The apostle uses this expression to say that each knee should be bent in the name of Christ, of all those in heaven, on earth and in the underworld. On the other hand, we are used to saying, that those in heaven and those in the underworld have no bodies to kneel with, as well as the souls which became separated from their earthly bodies." 42

From here on this expression occurs in many other texts as an exact quotation or periphrasis of St. Paul and is often related to, or replaced by, the Greek verb

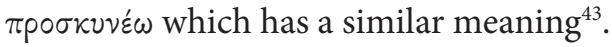

\footnotetext{
${ }^{41}$ Origenes, Fragmenta ex commentariis in epistulam ad Ephesios, sect. 15, 1-7 (Eph. 3, 14). Texts cited after Thesaurus Linguae Graecae.

${ }^{42}$ I thank Anna Lazarova for translating this passage from Greek to Bulgarian.

${ }^{43}$ See, for example, the following texts:
}

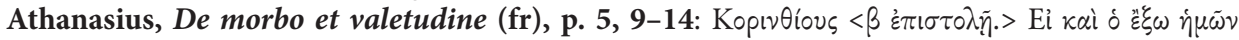

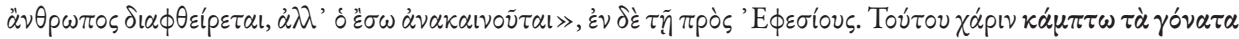

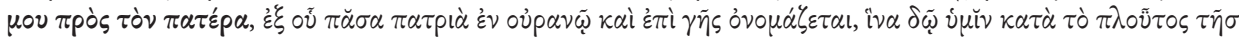

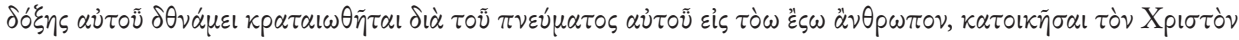
$\delta i \dot{\alpha} \tau \tilde{\eta} \varsigma \pi i \sigma \tau \varepsilon \omega \zeta \bar{\varepsilon} \nu \tau \alpha \check{\iota} \varsigma \alpha \alpha \rho$.

Epiphanius, Panarion (56 Adversus haereses), vol. III, p. 274, 19-28: $\eta \dot{\eta} \delta \dot{\varepsilon} \varepsilon \kappa \kappa \lambda \eta \sigma i \alpha ~ \pi \varepsilon \pi i ́ \sigma \tau \varepsilon v \kappa \varepsilon v$

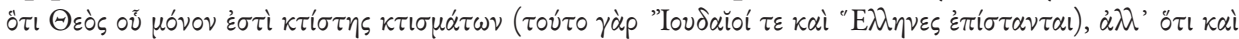

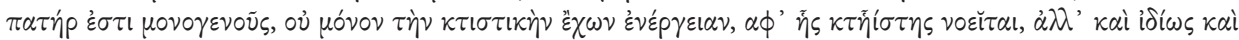

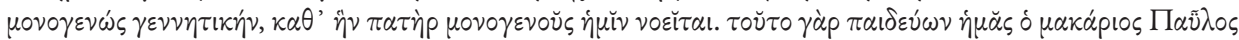

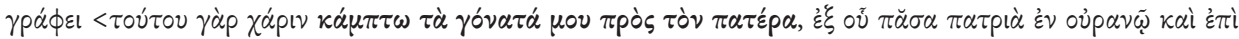

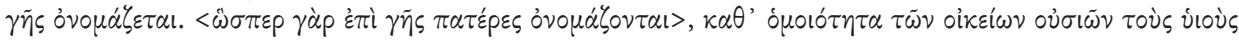

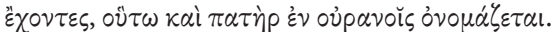


As for the straight walk which indisputably derives from the Greek o $\theta_{0} \pi \circ \delta \varepsilon$ w ('to walk straight or in the right way'), it always refers to the notion of how the king should behave. I only give two examples. The first is taken from St. Paul's

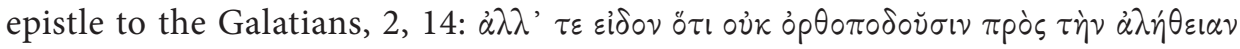

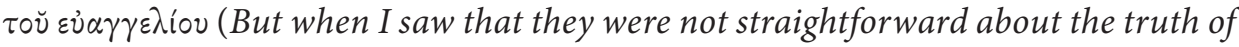
the gospel...). Another version of this expression in Greek is o $p \theta \dot{\alpha} \beta a \delta i \zeta \varepsilon \imath$. We find it in a homily on Mathew's gospel by St. John Chrysostom: O

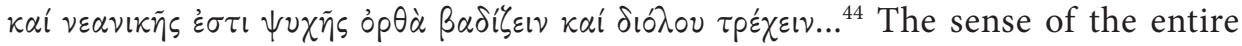
passage is the following: "It is not appropriate to such a noble but still youthful soul to walk straight (in the right way) and to run the whole way". The second part clarifies this notion: “...(to walk straight) and despite numerous laurels and victories, the greatest temptation to the soul, to be capable of returning to the right way".

The tradition we have followed so far and which we take to be related to our text, is undoubtedly a canon of approved topoi for praising the emperor (or king). But, as Paul Magdalino says, the frequency with which the emperor was praised made the imperial image a stereotype. Yet it also ensured that the stereotype was infinitely variable ${ }^{45}$. I also quote L. Graševa who (long before Magdalino) writes in her preface to The Oratory Prose: Each canonic art, such as ceremonial eloquence in the Middle Ages, achieves its esthetic norms through an unlimited number of variations $^{46}$. For this reason we will not even find two completely identical imperial

\section{Basilius, De baptismo libri duo, PG, vol. XXXI, col. 1561, 20-28:}

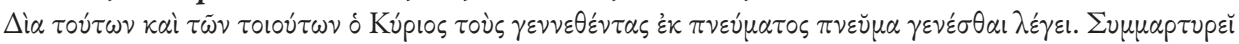

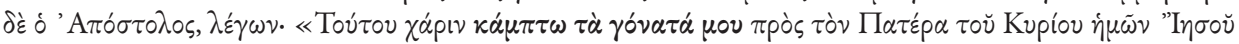

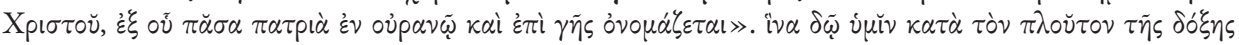

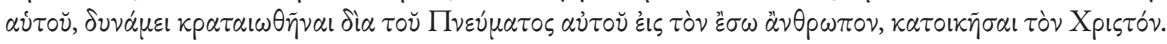

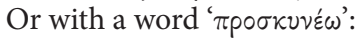

Septuaginta, Paralipomenon I sive Chronicon I, 19, 1 - 21, 3:

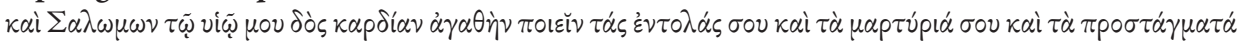

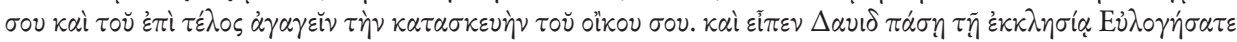

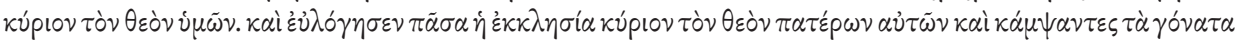

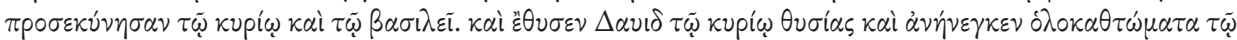

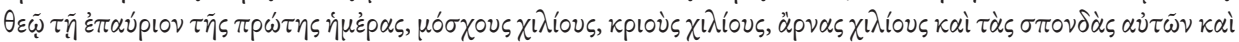

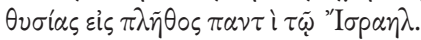

Basilius, In ebriosos, PG, vol. XXXI, col. 460, 48 - 461, 5:

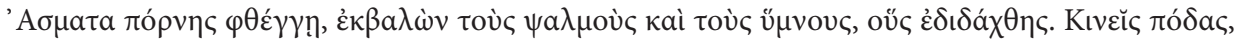

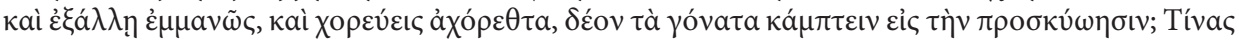

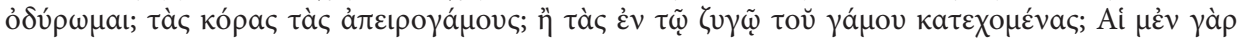

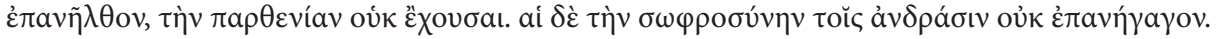

${ }^{44}$ PG, vol. LVII, col. 342, 18.

${ }^{45}$ P. Magdalino, The Emperor and His Image, [in:] idem, The Empire of Manuel I Komnenos, 1143-1180, Cambridge 1993, p. 418.

46 Л. ГРАШЕВА, op. cit., p. 14. 
encomia, since none of them strictly follows Menander's rules. What Byzantine encomiasts and the Bulgarian author of king Ivan Alexander's praise derive from Menander and other sources is not an applied model, but a sum of structuring principles, motives and techniques which can vary innumerably. As Magdalino says, a successful encomium is the one that renews the old topoi through a skilled use of the hyperboles and comparisons. ${ }^{47}$ I think that this is the case of king Ivan Alexander's praise in the Sofia psalter.

\section{II}

As noted above, Ivan Alexander is the Bulgarian ruler of whom we possess the greatest number of portraits. Here I consider two of them:

1. The earliest of them are preserved among the illuminations of the chronicle by Constantine Manasses (Vatican Library, cod. Slavo 2), dated to $1344-1345^{48}$. In the middle of $\mathrm{f} .1$, Ivan Alexander is depicted on a red subpaedaneum with an angel above him who places a second crown on his head. Christ is standing on the king's right side half-turned toward him, carrying a scroll in his hand. On his other side is the chronicle's author, Constantine Manasses. According to Hans Belting, the Byzantine text of the chronicle did not contain such an illumination and the Bulgarian illustrator used the chrysobouls of Byzantine emperors as a pattern without applying it directly. The fact that Christ is moved from the center and 'demoted' to the king's entourage excludes in itself the usage of a ready-made Byzantine pattern $^{49}$. Ivan Dujčev claims that the model of the Byzantine emperor Manuel I Comnenus was used as a pattern for the first illumination, since the chronicle was written in his time ${ }^{50}$. However, I think that there was no Byzantine pattern comparing the Bulgarian king and king David as equals. This is also the conclusion drawn by Ivan Božilov who devotes a special research to the relation between the text and the illumination in Manasses' chronicle: ... the miniature illuminates the addition or, to be more precise, the replacement of the Greek text by a Bulgarian one on f. 91v; it mentions Ivan Alexander who is also depicted on the illumination. The fact that the Greek text names Manuel I Comnenus does not auto-

\footnotetext{
${ }^{47}$ P. Magdalino, op.cit., p. 418.

${ }^{48}$ B. Filov, Les miniatures de la Chronique de Manassès à la Bibliothèque du Vatican (Cod. Vat. Slav. II). Sofia 1927. Cf. IDEм, Миниатюрите на Манасиевата хроника във Ватиканската библиотека, София 1937; I. DujčEv, The Miniatures of the Chronicle of Manasse, Sofia 1963; IDEм, Миниатюрите на Манасиевата тетопис, София 1962; J. Spatнarakis, The Portrait in Byzantine illuminated manuscripts, Leiden 1976, p. 160-165, ill. 102-105 ; А. ДжуровА, Хиляда години българска рбкописна книга. Орнамент и миниатюра, София 1981, p. 46, ill. 170. The newest edition: Constantine Manasses, Synopsis Chroniki. Codex Vaticano Slavo 2, 1344-45, Атина 2007 (with participation of A. Džurova and V. Velinova), was unavailable.

${ }^{49}$ H. Belting, Das illuminierte Buch in der spätbyzantinschen Gesellschaft, Heidelberg 1970, p. 21.

${ }^{50}$ I. DUJČEV, op. cit., p. 32.
} 
matically imply that there existed a Byzantine manuscript depicting the emperor. ${ }^{51}$ For this reason the illumination remains unique.

It is important to note that almost all recent research on the illumination in the Manasses chronicle draw the conclusion that no illuminated Byzantine manuscripts were used as a pattern for the Bulgarian one. Ivan Božilov is categorical on this:

the unknown authors produced a new book, differing from both the Greek (additions and titles) and the Bulgarian models, as well as from the Synodos and the Toulcha manuscripts (the Trojan parable and 79 illuminations); a new book designed for decorating the king's library, for the enjoyment of the members of the royal family and for offering the king's heirs a way into humanity's past - as it was seen by Constantine Manasses and as reworked by the anonymous Bulgarian authors ${ }^{52}$.

Even the less-categorical scholars think that the problem of the origin of the illuminations in the Vatican's Manasses Chronicle still remains unsolved ${ }^{53}$.

2. Ivan Alexander's image on f. 91 is particularly interesting in regard to the notion of the perfect ruler. The Bulgarian king is depicted together with king David who blesses him, and an angel who gives him a spear symbolizing the divine origin of the king's power ${ }^{54}$. On David's scroll there is a part of Psalm 21 which praises the king's power. Christopher Walter says: It is the beginning of Psalm 20(21), that which is illustrated by a coronation in the Bristol, Theodore and Barberini Psalters, and which is paraphrased in the prayer recited by the patriarch in the rite of coronation. There is no doubt that we have here two successive stages of he same scene: the angel brings the crown and Tsar John Alexander wears the crown. ${ }^{55}$ This iconographic formula is genuinely Byzantine, although we possess no similar composition in Byzantine art. In the illumination in Manasses' chronicle, Ivan Alexander's image is not only directly compared to the 'portrait' of the biblical king, but also depicts the Bulgarian king as equal to David. This is indisputably impudent, similar to the introductory illumination, as we noted ${ }^{56}$.

\footnotetext{
${ }^{51}$ И. Божилов, Ватиканският Манасий (Cod.Vat. Slavo 2). Текст и миниатюра, ПИ 2, 1996, p. 11.

${ }_{52}$ И. Божилов, op. cit., p. 12.

${ }^{53}$ Б. Цветковић, О двема минијатурама у Cod. Vatic. Slavo 2, КЗб 9/10, 2003, p. 125. Cf.

Б. Цветкович. За две миниатюри в Cod. Vat. Slavo 2, ПИ 1, 2000, p. 11-16.

${ }^{54}$ On that iconographic formula see В. Ђурић, Нови Исус Навин, Зог 14, 1983, p. 5-16.

${ }^{55}$ C. WALter, The iconographical sources for the coronation of Milutin and Simonida at Gračanica, [in:] Византијска уметност почетком XIV века, Београд 1978, p. 199.

${ }^{56}$ On the other images of Ivan Alexander in this manuscript see: Е. БАКАЛОвА, Ктиторските портрети на иар Иван Александгр като израз на политическата и религиозната идеология на епохата, ПИ 4, 1985, p. 45-57; ЕADEM, Society and Art in Bulgaria in the $14^{\text {th }}$ century, BBg 8, 1986, p. 23-32. Cf. T. Velmans, La Chronique illustrée de Constantine Manassès, [in:] Byzance,
} 
Concerning the comparison with David, already Menander emphasizes that

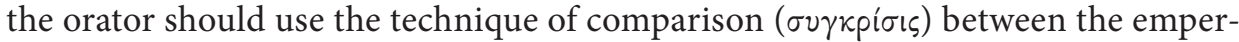
or and other historical figures. Actually, the essential aspect of Byzantine ideology is the construction of lasting formulas of virtuous rulers based on standard models and metaphors. These formulas are constructed mainly by the technique of comparison which, as Henry Maguire points out, is the main instrument of Byzantine rhetoric. Although the comparison is widely used in laic and religious literature, the habit of comparison is very important for an understanding of Byzantine art, because it was especially applicable to visual media ${ }^{57}$

Eusebius of Caesarea already calls Constantine the Great "new Moses", but also "savior of the chosen people" and "new David". Interestingly, not every Byzantine emperor is compared to David. We may note a specific tendency to compare the emperors of the Comnenian dynasty with those - Justinian and Heraclius - related to the most glorious times of the Eastern Roman empire ${ }^{58}$. Justinian was called "new David", due to his building the St. Sofia cathedral, compared to the foundation of the Jerusalem temple ${ }^{59}$. An episode of Heraclius' military campaigns strongly resembles the battle between David and Goliath. Byzantine historians report that during the war with the Persian ruler Chosroes (627), Heraclius fought with general Rhazatis and decapitates his rival just like the biblical king ${ }^{60}$. Stephen $H$. Wander finds another interesting proof of the comparison between emperor Heraclius' victory over the Persian ruler and David's victory over Goliath ${ }^{61}$. It is part of Fredegar's chronicle, a Frankish author from Burgundy $\left(7^{\text {th }}\right.$ c.) who describes the duel between Heraclius and Chosroes and calls the Byzantine emperor "a second David".

According to Alexander Kazhdan, the imperial prestige of the Comnenoi is directly related to an unprecedented militarism ${ }^{62}$. Its most striking expression is to be found in the texts praising Manuel I Comnenus who, on Magdalino's view, is the most celebrated of the Byzantine emperors ${ }^{63}$. He is regarded as a model of all David's virtues, lacking no attributes of the latter's reign. There are numerous and concrete comparisons between Basil I of the Macedonian dynasty and David recalling the emperor's military success. But the comparison with David has fur-

les Slaves et l'Occident: Études sur l'art paléochrétien et médiéval, London 2001, p. 175-230.

${ }^{57}$ H. Maguire, The Art of Comparing in Byzantium, ArtB 70, 1988, p. 89.

${ }^{58}$ P. Magdalino, The Emperor and His Image..., p. 421.

${ }^{59}$ G. Dagron, Constantinople imaginaire, Étude sur les recueil des Patria, Paris 1984, p. 293.

${ }^{60}$ Nicephorus, Opuscula historica, ed. C. de Boor, Lipsiae 1880, p. 19; Theophanes, Chronographia, ed. I. Classen, Bonnae 1851, p. 489-492.

${ }^{61}$ S.H. WANDER, The Cyprus Plates and the Chronicle of Fredegar, DOP 29, 1975, p. 346.

${ }^{62}$ A. Kazhdan, The aristocracy and the imperial ideal, [in:] The Byzantine aristocracy, ed. M. ANGOLD, Oxford 1984, p. 43-57.

${ }^{63}$ P. Magdalino, op. cit., p. 414. 
ther aspects. Gilbert Dagron writes:

similarly to David who inherits Saul's kingdom, Basil replaces the hated emperor Michael III; similarly to David who, to redeem his bloody sin, lost his first-born son by Bathsheba but was later given a second son - "the wise Solomon", Basil claimed that he lost his older son Constantine in 879 due to divine vengeance, and called his second son Leo "the wise", although he did not much love him ${ }^{64}$.

In the $13^{\text {th }}$ c. Michael VIII Palaeologus, protector of Constantinople, was praised as „new David”, just as David protected Jerusalem ${ }^{65}$. In the encomia of Andronicus II, the comparison between Constantinople and Jerusalem remains, while the emperor is rather compared to Plato ${ }^{66}$. As far as I know, the comparison with David almost disappears in the $14^{\text {th }} \mathrm{c}$. Neither John Cantacuzenus nor John V, nor Manuel II Palaeologus, are compared to David, let alone an emperor like John VII Palaelogus, whose activity brought more damage than profit to the state ${ }^{67}$.

It clearly follows that both the comparison with Alexander the Great in Ivan Alexander's praise in the Sofia psalter and his comparison with David in the illumination in Manasses' chronicle reflect the historical situation in the third decade of the $14^{\text {th }} \mathrm{C}$.

As we noted above, the first ten years of Ivan Alexander's reign (1331-1371) are a time of internal stability and successful military campaigns, due to which he is compared to the biblical king David. On $18^{\text {th }}$ July 1331, he wins a great battle against the Roman army of Andronicus III Palaeologus and succeeds in taking back the territories lost earlier on. The treaty required the marriage of his firstborn son and the Byzantine's young daughter Maria, which took place soon after ${ }^{68}$. At the same time, Ivan Alexander managed to improve the relations with Serbia, as in 1332 his sister Helen married the Serbian king Stephen Dušan. Ivan Božilov writes:

When adding to these two political successes the liquidation of Belaur's rebellion in Vidin, it becomes clear that only a year after his coronation, Ivan Alexander kept full power in

${ }^{64}$ G. Dagron, Empereur et prêtre. Étude sur le „césaropapisme” byzantin, Paris 1996, p. 206. V. Stanković writes: Давидов пример је био близак свим цзаревима, који су престо усвоили своим способностима, захвалујући својој тиххң а не крви, као што је Соломон био стални узор али и такмаи у свим градителским подухватима иарева - В. СТАнковић, Цариградски патријарси и цареви. Македонске династије, Београд 2003, р. 250.

${ }^{65}$ J. Previale, Un panegirico inedito per Michele VIII Paleologo (Vat. gr. 1409, ff. 270 r.-275 v.), BZ 42, 1959, p. 11.

${ }^{66}$ Н. РАдОшЕВИћ, Похвална слова цару Андронику ІІ Палеологу, ЗРВИ 21, 1982, p. 61-81.

${ }^{67}$ С. МешАновит, Јован VII Палеолог, Београд 1996, р. 133.

${ }^{68}$ И. Божилов, Второ българско иарство (1186-1393/96), [in:] И. Божилов, В. МутАфчиЕвА, К. Косев, А. ПАНТев, С. ГръНчАРОв, История на България, София 1993, p. 109-110. 
Bulgaria and successfully healed the recent wounds (the defeat by Serbia and the territorial losses to the Byzantine empire $)^{69}$.

However, in the fourth decade of the $14^{\text {th }}$ c., during the civil war in Byzantium, the Bulgarian king was inexplicably passive, while Stephen Dušan took control of almost all Macedonia and proclaimed himself "king of all Serbian, Greek and Bulgarian lands". It is obvious that this is one of the reasons why there are no literary or visual encomia of the king's reign from this period. In fact, the situation in Bulgaria already changed in the second half of Ivan Alexander's reign. From the fifth decade of the $14^{\text {th }} \mathrm{c}$. on, there are many Bulgarian translations of Byzantine texts related to theological disputes favoring hesychasm. We know that Ivan Alexander not only supported the monks of Paroria but, in his ecclesiastic policy, also followed the famous hesychast Theodosius - a disciple of Gregory Sinaites and close to Callistus, patriarch of Constantinople. If we turn to the visual sources, we can notice that in the sixties, the king was no longer compared to David but to Constantine and Helen, as indicated by the narthex of the ossuary in Bachkovo monastery ${ }^{70}$. The model patriarch Euthymius recommends to Ivan Šišman, Ivan Alexander's heir, is that of Constantine the Great, as appears in his Encomium of Constantine and Helen.

In this context, we should emphasize that the comparison between Ivan Alexander and king David in the illumination of Manasses' chronicle (1344-1345) is one of the last comparisons of the $14^{\text {th }} \mathrm{c}^{71}$ Resulting from the same historical situation, we have another short praise of Ivan Alexander in the Sofia psalter, the so-called Pesnivec, ordered by the king in 1337, as well as his comparison with Alexander the Great in the Encomium. Both artifacts - the illumination and the encomium - are created about the same time and are related to the same historical situation in this particular historical and ideological context. A little later, at the beginning of the fourth decade of the $14^{\text {th }} \mathrm{c}$., the historical situation changes significantly and the ideas underlying these artifacts are no longer actual.

Abstract. The paper is an attempt to provide some information about the concept of the perfect ruler, as saved in the literature and the fine arts of the medieval Bulgaria, and which are related to the name of the king Ivan Alexander. The first part of the text is of theoretical character, showing how the ancient Greek literature presents the ideal ruler. The second one

\footnotetext{
${ }^{69}$ Ibidem, p. 110.

${ }^{70}$ On Bačkovo see above, p. 26. On the later images of Ivan Alexander see Е. Бакалова, Ктиторските портрети..., p. 45-57; EADEM, Society and Art..., p. 23-32.

${ }^{71}$ More fully on this issue see E. BAKalova, King David as a Model for the Christian Ruler: Some Visual Sources, [in:] Biblical Models of Power and Law/Modèles bibliques du pouvoir et de la loi, ed. I. Biliarski, R.G. PăUn, Frankfurt am Main et al. 2008 [Rechthistorische Reihe 366], p. 93-133.
} 
points out the characteristics of the portrayal of Ivan Alexander, as saved in both literary monuments (praises of the king in the Sofia psalter, so-called Pesnivec, 1337), and iconographical ones (a famous chronicle by Constantine Manasses, 1345-1346).

Translated by Anita Kasabova and Vladimir Marinov

Elka Bakalova

Bulgarian Academy of Science

Khan Krum str 49

1142 Sofia, Bulgaria

elka.bakalova@gmail.com 


\section{Eulogy of the Bulgarian King Ivan Alexander in the Sofia Psalter of 1337} [...]

For as we have gathered let us praise God and sing a solemn song to Christ, the King crown-giver and Lord of us all who has given to us the great commander and King of Kings, the great Ivan Alexander, the most orthodox of all, ... and leader in war, and mighty in battles, gracious, benevolent, pink-cheeked, kind-sighted, handsome in appearance, with bent knees and upright walking, gazing sweetly over all, righteous beyond words, judge of orphans and widows. Hence I will say, who, among us, after heaving seen the King, would return grieving to his home? In his military might he seems to me like a second Alexander of ancient times. Like him [Ivan Alexander] from the very beginning [of his reign] took many cities with fortitude and courage. So he appears before us, the great Ivan Alexander, ruling over all the Bulgarians, he, who has proven himself in difficult and hard battles; who has powerfully overcome the Greek King and when the latter was at a loss, he captured him and took the fortified towns: Nessebar ${ }^{72}$ and all of the Pomorie ${ }^{73}$ together with Romania, as well as Bdin and all of the lower Danube even to the Morava river. The rest of the towns and villages, countries and countryside fell at his feet. And having captured all his enemies, he triumphed over them establishing a solid silence in the Universe. It seems to me that this King appeared as a new Constantine among the Kings in his faith and piety, heart and character, having as scepter the triumphant Cross; when bearing and showing this standard he drove away and dismissed all resisting and arrogant forces... No other since the first [Bulgarian] kings seems to me equal to this great King Ivan Alexander, Glory and Praise of all Bulgarians. Look, all you young and old, and raise your flags in combats for the glorious King of Bulgaria. Come forth, now you patriarchs and bishops, monks and ascetics, judges, slaves and freemen, dignitaries and all the king's men; and rejoice you with inexpressible joy and render glory to the great King Christ our God, the wreath-giver and raise to him your victorious song: Oh, Holy Trinity, save the Bulgarian King, protect and strengthen him, give him victory over his enemies and ... endow him with longevity, O Lord of us all. For I, while weaving joyful praises, say: Rejoice, o King of the Bulgarians, King of Kings. Rejoice chosen by God, rejoice o merciful, Rejoice, o crowned by God! Rejoice guarded by God! Rejoice leader in war-times! Rejoice, intercessor of the faithful! Rejoice Bulgarian Glory and Praise! Rejoice King Alexander! Rejoice Ivan! Rejoice, together with your pious spouse, Queen Theodora! Rejoice, together with your sweet children - Michael King, and Asen, and Sratzimir and Asen! Rejoice, o, town of Tarnovo! Rejoice his towns and countries! Rejoice thee and rejoice again for that you have such a King! Let God strengthen them in their power and let God offer them heavenly Kingdom, and let him settle them in the palace of heaven for ever, now and ever and unto ages of ages. Amen.

translated from old Bulgarian by prof. Oleg Grabar, Institute for Advanced Study, Princeton 1999

\footnotetext{
${ }_{72}$ Messambria on the Black Sea.

${ }^{73}$ The Black Sea coast.
} 